\title{
THE IMPACT OF NEWSPAPERS ON CONSUMER CONFIDENCE: DOES SPIN BIAS EXIST?
}

\author{
KAREL-JAN ALSEM \\ STEVEN BRAKMAN \\ LEX HOOGDUIN \\ GERARD KUPER
}

CESIFO WORKING PAPER NO. 1328

CATEGORY 10: EMPIRICAL AND THEORETICAL METHODS

NOVEMBER 2004

\footnotetext{
An electronic version of the paper may be downloaded

- from the SSRN website:

www.SSRN.com

- from the CESifo website:

www.CESifo.de
} 


\title{
THE IMPACT OF NEWSPAPERS ON CONSUMER CONFIDENCE: DOES SPIN BIAS EXIST?
}

\begin{abstract}
It is sometimes argued that news reports in the media suffer from biased reporting. Mullainathan and Shleifer (2002) argue that there are two types of media bias. One bias, called ideology, reflects a news outlet's desire to affect reader opinions in a particular direction. The second bias, referred to as spin, reflects the outlet's attempt to simply create a memorable story. Competition between outlets can eliminate the effect of ideological bias, but increases the incentive to spin stories. We examine whether we find some evidence of spin in Dutch newspaper reporting on the state of the economy. If newspapers are indeed able to create memorable stories this should, according to our hypothesis, affect the opinion of readers with respect to the state of the economy. Sentiments about the actual state of the economy could be magnified by spin. As a result, consumer confidence - a variable that routinely measures the opinion on the state of the economy - can be expected to be affected not only by economic fundamentals, but also by the way these fundamentals are reported. We construct a variable that reflects the way consumers perceive economic news reported in newspapers. We find that this variable indeed has a significant impact on consumer confidence, which is short-lived.
\end{abstract}

JEL Code: E20, E21, E30.

Karel-Jan Alsem
University of Groningen
Faculty of Economics
PO Box 800
9700 AV Groningen
The Netherlands
k.j.alsem@eco.rug.nl
Lex Hoogduin
The Netherlands Bank
Westeindel 1017 ZN
POBox98
1000AB Amsterdam
The Netherlands
l.h.hoogduin@dub.nl

Steven Brakman
University of Groningen
Faculty of Economics
PO Box 800
9700 AV Groningen
The Netherlands
s.brakman@eco.rug.nl
Gerard Kuper
University of Groningen
Faculty of Economics
POBox 800
9700AV Groningen
The Netherlands
g.h.kuper@eco.rug.nl

We like to thank Tammo Bijmolt, Peter van Els, Jan Jacobs, Ger Lanjouw, Peter Leeflang, Ad Stokman and Peter Zwart for comments on an earlier version of this paper. Research assistance by Mark Dijkstra is gratefully acknowledged. 


\section{INTRODUCTION}

Mullainathan and Shleifer (2002) distinguish between two types of biased newspaper reporting. Ideological bias is caused by differences in the ideology of newspapers.

Competition between media can eliminate the effect of ideological bias. Ideological biases cancel out in the aggregate of all stories available to readers. The truth is "in the middle". The second source of bias, referred to as spin, reflects a newspaper's attempt to create a memorable story. Newspapers compete with each other (and with alternative sources of information) for public attention in order to survive in the media market. This implies that they are in the business of writing stories that capture the attention of potential readers. They aim for interesting stories that competitors do not have. A successful newspaper shows what is and what is not interesting to read; it not only reports news, but, to some extent, also defines news. If it succeeds in presenting the news in an attractive manner, potential readers are encouraged to use a specific newspaper as the main source of information. Exaggeration is one way to attract the reader's attention. However, that is literally not the end of the story. Competing newspapers often pick up a story reported by another newspaper and write followup stories. These follow-up stories are only interesting to readers, if they add something to the original story to make it memorable. In the process, the facts or non-facts are presented in a forceful way and spin bias is the result. Different from ideological bias, spin bias is not eliminated in the market or even reduced by competition, but reinforced: the newspaper with the most memorable stories, sells the most copies.

Competition between newspapers creates exaggeration - or spin - of stories and/or facts in order to make them memorable. Once the stories are stuck in the minds of readers we assume that this affects their opinion. Our objective is to test whether such a bias can be identified in reports on the state of the economy in Dutch newspapers. As such we aim to test the theory of Mullainathan and Shleifer for a large segment of the Dutch media market.

We assume that competition in the Dutch daily newspaper market, which seems to be fierce, stimulates newspapers to exaggerate their stories in order to become memorable to readers. Consumers read such reports and consumer confidence, which is a measure for consumers' assessment of the state of the economy, may be affected. Consumer confidence is of course not only affected by spin but also by the actual state of the economy, which is reflected by 
objective economic data. Our hypothesis is that consumer sentiments are determined by what consumers read in the papers. If spin exists, consumers have a biased picture of the state of the economy. The perceived business cycle by consumers thus shows larger amplitude than the actual business cycle or, more in general, perceived economic variables are more volatile than actually is the case. Spin can thus be interpreted as a magnifying force with respect to consumer sentiments about actual facts on the state of the economy. We test the spin hypothesis for consumer confidence in two ways.

First, we examine whether consumer confidence is more volatile than producer confidence. The latter is not influenced by sentiments, since it is measured by objective economic variables, like the order position and changes in stocks. Second, we develop a measure of how consumers perceive the state of the economy reading newspapers and estimate whether this measure has a larger impact on consumer confidence than it does on producer confidence. If this is the case, we take this as evidence of the existence of spin bias. At this point it is important to indicate that we do not look into the problem whether or not changes in consumer confidence have an effect on the real economy, but only if consumer confidence itself is affected by news. The relation between consumer confidence and the real economy is still not completely understood, and appears to be weak (see Jansen 2003, Ludvigson, 2004). On the basis of this literature one can safely conclude that producer and consumer confidence are influenced by different variables. This strengthens our assumption that producer confidence can be used as a benchmark relative to consumer confidence and that they can be treated as different variables.

This article is structured as follows. In section 2 the measurement of consumer confidence and the way we estimate consumers' perception of the state of the economy from newspaper reports (from now called MEDIA) are discussed. Section 3 looks at the question if volatility of consumer confidence is larger than that of producer confidence and whether MEDIA has a significant impact on consumer confidence relative to producer confidence. Section 4 employs VAR analysis to disentangle the interaction between MEDIA, consumer- and producer confidence and, in a second estimate, a stock market index. Section 5 concludes. 


\section{MEASUREMENT OF CONFIDENCE AND MEDIA}

Consumer- and producer confidence are routinely measured by Statistics Netherlands (CBS). Consumer confidence reflects (changes) in public opinion about the state of the economy. A panel of (approximately) 1000 consumers have to answer questions like: do you expect the economic climate to improve or not; do you expect that your financial situation will improve in the near future; do you expect to make a large purchase in the near future? Questions like these are specifically asked to find out whether or not public opinion about the economy has changed. Why opinion might have changed is not part of the questionnaire. The frequency is monthly. ${ }^{3}$

Producer confidence is also published by the CBS. This variable is a combination of three questions posed to firms in the CBS panel. These questions relate to: the current stock of orders in the next three months, the expected orders in the next three months, and how they interpret the stock of finished products. The variable is less of a psychological nature than consumer confidence and as such is a more objective reflection of the state of the economy. Newspaper reporting presumably does not immediately influence this variable.

\section{CONSTRUCTING MEDIA}

The data about economic news was collected by asking experts to judge a large set of newspapers. Experts were used since we need an objective measure of economic news. This section describes how these expert data were collected.

\section{Choice of media}

We want to investigate whether or not media reporting about the state of the economy affects consumer confidence. Economic news is spread through different media: TV, radio, newspapers, magazines, Internet etc. In this study we choose to use national newspapers as our main source, because newspapers offer day-to-day news, have a high reach, and are relatively easy to present to a panel of experts.

Since we have (60) monthly data on economic variables, we also need monthly observations on economic news. We choose one fixed day per month, the first Saturday, as the observation

\footnotetext{
${ }^{3}$ See Jansen (2003).
} 
date for $M E D I A$. A fixed day per month avoids time biases as to the relation to producer and consumer confidence, and they are also collected in the first 10 days of the month. In principle more data points could be collected. However, this would lead to a heavy (time) burden for the experts. The pre-tests showed that the time load on the experts rapidly increases with more questions or more pages that had to be answered or judged. A potential drawback in choosing a single day is that monthly observations are affected by what is reported on a specific day. On the other hand it might be expected that very interesting (economic) news will also receive attention on other days, including the day of observation.

Newspapers differ in the way they write about (economic) news. In order to reduce possible bias, two newspapers aimed at different target groups were used in the study: a large, popular morning newspaper (De Telegraaf) and a somewhat smaller evening newspaper, more directed at higher social classes (NRC-Handelsblad). De Telegraaf is market leader with a market share, in paid circulation of national newspapers, of $43 \%$ and a reach of $21 \%$ in Dutch population of 13 years and older (Mediafeitenboekje, 2003). Market share of NRC in circulation of national newspapers is $15 \%$ and reach is $4 \%$. De Telegraaf is known not to shy away from relatively large letter types to present the news; the NRC-Handelsblad is more modest in this respect. It might be expected that these two newspapers together provide a good impression of economic news reporting in the media.

From each of the two newspapers 60 were used: the newspaper of the first Saturday of each month in the period January 1998 through December 2002. From these newspapers the front page and the main economic page were copied, which results in four pages per day: the front page and economic page of De Telegraaf and NRC Handelsblad. The pages were copied (half size of the original) from microfilms containing the original newspapers. So, in the end we had 60 sets of 4 pages. These sets were used for the data collection. The collection took place in 2004. So the assessment of economic news is done afterwards. This is done since no alternative data are available. This could have two disadvantages. First, with hindsight some facts might be judged differently than if these facts are judged in 'real' time.

Second, the current mood might affect the interpretation of historical facts. However, the latter bias affects all observations and does not affect the fluctuations in the time series. 


\section{Pre-tests}

Before presenting the data to the panel of experts we performed a number of pre-tests. We (subsequently) asked three Faculty members of the Economics Department (University of Groningen) to perform the task. During these pre-tests we improved the way of presenting the pages, reduced the number of questions and pages (in order to reduce the time burden of the panel), and most importantly adjusted the text of the measurement scale. We dropped, for example, the following question that was put forward to the experts: In these newspapers the economic news receives much attention. This question is a biased measure in the sense that only the economic pages were shown to the panel. For our purposes it is crucial that we measure the way economic news is reported in the newspaper and not mimic measurement of consumer confidence.

\section{Measurement scale}

Ultimately the experts were asked to give an overall view of the four pages (reading in detail was said not to be necessary) and then assess each set of pages on the following two dimensions, using the widely used Likert scale (completely disagree, disagree, neutral, agree, completely agree, subsequently coded as 1 to 5 ):

- The news coverage in these newspapers is such that I judge the economic situation in our country to be positive. (Give your opinion relatively to what you assume to be a normal economic situation).

The question measures the 'economic mood' of the newspapers and we are ultimately only interested to know what the overall impression of the experts was.

The 60 page samples of 4 pages each were presented in chronological order. This may lead to cumulative effects of the news presented: for example, if two subsequent observations present some indication of slightly negative economic developments, a third negative news item may lead to the conclusion of a judge that the economy is slowing down. These kind of cumulative effects, however, also appear in real life.

\section{Data collection and reliability}

Experts were used to perform the task of giving a rating about economic news in the newspapers. An 'expert' is a person who can be expected to perform a given task in a reliable 
way. Ideally one hopes that all experts will give about the same rating. The use of experts in assessing communication is widely used (see e.g. Woltman Elpers et al., 2003). Furthermore, the economic pages of newspapers are of special interest to our panel, although their opinion might differ from a panel not necessarily interested in economic news.

The experts in our study were graduate students in Economics from a Dutch university. The minimal number of experts to be used depends on the difficulty of the task and the degree of consensus experts show in their opinions.

We selected 20 students (10 male and 10 female) for the task and analysed afterwards if there is consensus among the experts. If there is no consensus the method of data collection and/or number of experts should be changed.

The degree to which experts show consensus in their assessments is a measure of the consistency and reliability of their task. A measure of consensus among experts is the Cronbach's alpha (or coefficient alpha). This is the correlation between the experts. A value of alpha larger than 0.6 is considered to indicate sufficient internal consistency or reliability (Malhotra, 2003, p. 268). In our case the value of alpha is 0.77 , and indicates a sufficient agreement between the 20 judges on their assessment of the economic mood in the newspapers of the sample. ${ }^{4}$ This value of alpha also points out that it is not necessary to use additional experts. The mean of the scores in each month is used as the MEDIA variable in this study.

\section{DOES SPIN BIAS EXIST?: A FIRST LOOK}

Figure 1 shows the time series for consumer- and producer confidence, called $C C$ and $P C$, respectively, and MEDIA from 1998 until 2003.

\footnotetext{
${ }^{4}$ So, sample size is less relevant here than in most other (market) research using respondents since in the latter case a large sample size actually has to outweigh differences in answers between respondents.
} 


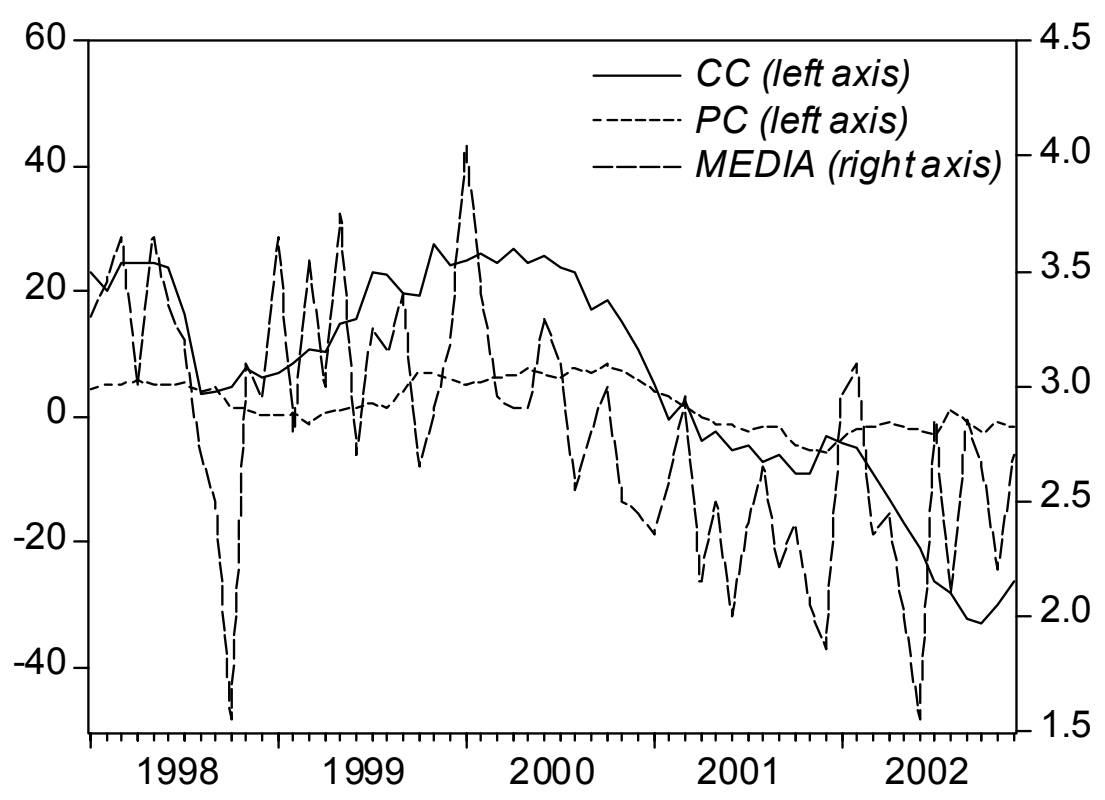

Figure 1 - Consumer confidence $(C C)$, producer confidence $(P C)$ and $M E D I A$

In the period under review the economy was initially booming, with very rapidly rising stock market and housing prices indicating an explosive development. In the course of 2000 the economy went into recession. These developments provided sufficient background for story telling and spin bias to occur. This period, therefore, seems a priori very appropriate for testing the spin bias hypothesis.

Figure 1 also depicts $M E D I A$. The variable is more volatile than both other variables and shows a seesaw pattern. This indicates that MEDIA has low persistence and that last month's news has not much impact on the assessment of the state of the economy in the current month. This is not surprising and in line with the view that yesterday's news is already forgotten today.

At the same time, the last years of the boom and the following recession are reflected in the assessments of the newspaper reports on the state of the economy. Before 2000 MEDIA is almost always higher than average, and after 2000 with a few exceptions lower than average. This is reasonable.

There are three observations, however, that require separate discussion. The first is a deep, but very short-lived trough in October 1998. This may be due to the Russian financial crisis. The 
second one is an above average assessment of the state of the economy in January and February 2002. It is not simple to relate this peak to a certain event. It may be a reflection of the feeling that the worst of the recession was over. In the same period and already somewhat earlier, producer confidence also recovered. Consumer confidence, however, deteriorated over the same period. In June of 2002, there was another deep trough, which may very well be related to the political turmoil in the Netherlands at the time. One new political party (LPF) had seen its support grow very rapidly and in May its leader was assassinated, just before the elections in May. At the same time it became clear that in the following four years the budget deficit would come out much higher than desired without large additional budget cuts. In public, politicians were painting a gloomy picture of the outlook for the Dutch economy. All in all, the general development of MEDIA seems in line with what one would expect (experiments with dummies for these events do not change the results described below).

There appears to be a systematic relation between consumer- and producer confidence. Table 1 shows that indeed these variables are highly correlated.

Table 1 - Simple correlation coefficients.

\begin{tabular}{llll}
\hline & $C C$ & $P C$ & $M E D I A$ \\
\hline Consumer confidence $(C C)$ & 1.00 & & \\
Producer confidence $(P C)$ & 0.78 & 1.00 & \\
MEDIA & 0.60 & 0.44 & 1.00 \\
\hline
\end{tabular}

$M E D I A$ is also to some extent correlated to consumer- and producer confidence, more to consumer than producer confidence, as expected.

Consumer confidence is far more volatile than producer confidence. The standard deviation of consumer confidence is more than four times as large as the standard deviation of producer confidence (17.5 and 3.8 respectively). This is consistent with the magnifying interpretation of the spin-bias hypothesis. Consumer and producer confidence are both determined by similar economic variables, but it is likely that consumer confidence is more liable to being affected by exaggerated media reports than producer confidence. Therefore, one expects consumer confidence to be more volatile. 
Our next step is to use regression analysis. Before we can properly do so, we first need to know the time series properties of the data. Both producer and consumer confidence turn out to be integrated of order 1, denoted as I(1), that is the series are stationary after first differencing ${ }^{5}$. One might expect the confidence variables to be stationary over a complete business cycle. However, the period 1998-2002 is probably not a complete business cycle. 1998 and 1999 were good years, but the next three years the economy was in recession. Therefore, unfavourable economic conditions are somewhat over represented in the sample. This is also clear from the average value of MEDIA of 2.79, which is lower than the "neutral" average of 3 . Of the 60 observations 22 have a value of 3 or higher. The difference between consumer and producer confidence is also I(1). MEDIA on the other hand is a stationary variable. Therefore, we estimate whether changes in the difference between consumer and producer confidence are significantly related to changes in MEDIA. Table 2 shows the results.

Table 2 - Simple regression results using ordinary least squares for the period February 1998 until December 2002.

\begin{tabular}{lcc}
\hline Model: $\Delta\left(C C_{t}-P C_{t}\right)=\beta_{1}+\beta_{2} \Delta M E D I A_{t}+\varepsilon_{t}$ \\
\hline Variable & Coefficient $t$-value ( $p$-value) \\
Constant & -0.714 & $-1.513(0.136)$ \\
$\Delta M E D I A$ & 1.593 & $1.917(0.060)$ \\
Observations & 59 & \\
Adjusted $R^{2}$ & 0.044 & \\
Standard error of regression & 3.625 & \\
Durbin-Watson & 1.681 & \\
\hline
\end{tabular}

MEDIA is almost, but not quite, significantly positive at the $5 \%$-level of significance. At the $10 \%$-level MEDIA is significantly positive. Therefore, we have found some, but not very strong, evidence of spin bias in this regression.

\footnotetext{
${ }^{5}$ The augmented Dickey-Fuller test statistics on levels including trend and intercept are $-1.159,-1.669$ and 6.232 for $C C, P C$ and $M E D I A$ respectively. The 5\% significance level is -3.489 . The augmented Dickey-Fuller test statistics on first differences including trend and intercept are -3.940 and-7.536 for $C C$ and $P C$ respectively. The 5\%-significance level is -2.914 .
} 


\section{DOES SPIN BIAS EXIST?: A CLOSER LOOK}

In the regression of the previous section we have implicitly assumed that media is an exogenous variable. However, MEDIA may have been affected by producer or consumer confidence. In writing their stories, journalists may have been influenced by the general mood among consumers and producers. Moreover, the confidence variables themselves might be related. This implies that all variables might be endogenous. This leads us to estimate a simultaneous system. Since there is not much theory about consumer and producer confidence, the most obvious choice is a specification and estimation of a VAR-model, which has the advantage that we can simply use ordinary least squares as estimation method. We start by a VAR with consumer- and producer confidence, but also look at a VAR that also includes a stock market index. The latter variable is often used as an explanatory variable for consumer confidence.

As we have seen (see footnote 4) testing for unit roots reveals that we cannot reject the nullhypothesis of a unit root for consumer confidence and producer confidence. 
The Johansen co-integration test indicates that these variables do not drift apart in the long run. ${ }^{6}$ This means that a stable long-run relationship between consumer confidence and producer confidence exists. This implies that we can model the VAR in levels and perform impulse-response analyses.

A VAR with $p$ lags is given in matrix notation as:

$\mathbf{y}_{t}=\mathbf{A}_{\mathbf{0}}+\mathbf{A}_{\mathbf{1}} \mathbf{y}_{t-1}+\ldots+\mathbf{A}_{\mathbf{p}} \mathbf{y}_{t-\mathrm{p}}+\varepsilon_{t}$

Where $\mathbf{y}_{t}$ is a nx1 vector of endogenous variables, $\mathbf{A}_{\mathbf{0}}$ is a $\mathrm{nx} 1$ vector of intercept terms, $\mathbf{A}_{1}, \ldots, \mathbf{A}_{\mathbf{p}}$ are nxn matrices of coefficients that relate lagged variables to current variables, and $\boldsymbol{\varepsilon}_{t}$ is a $\mathrm{nx} 1$ vector of error terms. Here $\mathrm{n}=3$ and $\mathbf{y}_{t}=\left(C C_{t}, P C_{t}, M E D I A_{t}\right)^{\prime}$.

Testing for the optimal lag length using information criteria by Akaike, Schwarz and HannanQuinn all suggest a lag length of 1 . This seems plausible. Table 3 reports the results of our unrestricted VAR (1), including a trend.

\footnotetext{
${ }^{6}$ Assuming no deterministic trend and one lag of the first differenced terms, both the trace test and the maxeigenvalue test indicate one cointegrating equation at the $5 \%$-significance level between $C C$ and $P C$. The cointegrating equation is: $C C=4.837 P C$, with the cointegrating coefficient having a standard error of .698.
} 
Table 3 - Unrestricted VAR(1) estimates for the period February 1998 until December 2002, $t$-values between brackets.

\begin{tabular}{llll}
\hline $\begin{array}{l}\text { Model: } \mathbf{y}_{t}=\mathbf{A}_{\mathbf{0}}+\mathbf{A}_{\mathbf{1}} \mathbf{y}_{t-1}+\varepsilon_{t} \\
\text { where } \mathbf{y}_{t}=(C C, P C, M E D I A)^{\prime}\end{array}$ & & \\
\hline & $C C$ & $P C$ & $M E D I A$ \\
\hline$C C(-1)$ & 0.997 & 0.041 & 0.011 \\
& $(16.554)$ & $(2.023)$ & $(1.463)$ \\
$P C(-1)$ & -0.230 & 0.791 & -0.013 \\
& $(-1.141)$ & $(11.750)$ & $(-0.552)$ \\
$M E D I A(-1)$ & -0.313 & 0.961 & 0.106 \\
& $(-0.272)$ & $(2.502)$ & $(0.756)$ \\
Constant & 2.430 & -3.228 & 2.738 \\
& $(0.639)$ & $(-2.545)$ & $(5.942)$ \\
Trend & -0.062 & 0.021 & -0.009 \\
& $(-1.380)$ & $(1.380)$ & $(-1.716)$ \\
Observations & 59 & 59 & 59 \\
Adjusted R & & & \\
Standard error of regression & 3.681 & 1.228 & 0.446 \\
F-statistic & 314.260 & 127.249 & 7.837 \\
Akaike AIC & 5.525 & 3.330 & 1.305 \\
\hline
\end{tabular}

On the basis of this VAR (1) we can analyse shocks to this system. We apply a one standard deviation shock to $M E D I A$ and analyse the response of consumer confidence $(C C)$ and producer confidence $(P C)^{7}$

\footnotetext{
${ }^{7}$ The Cholesky ordering in the impulse-response analysis is $M E D I A, C C$ and $P C$. This implies that MEDIA is not affected by $C C$ and $P C$, and that $C C$ is affected only by MEDIA and not by $P C . P C$ on the other hand is affected by both $M E D I A$ and $C C$. Generalized impulses, or alternative orderings, generate the same effects as shown in figure 2.
} 
Response to Cholesky One S.D. Innovations \pm 2 S.E.
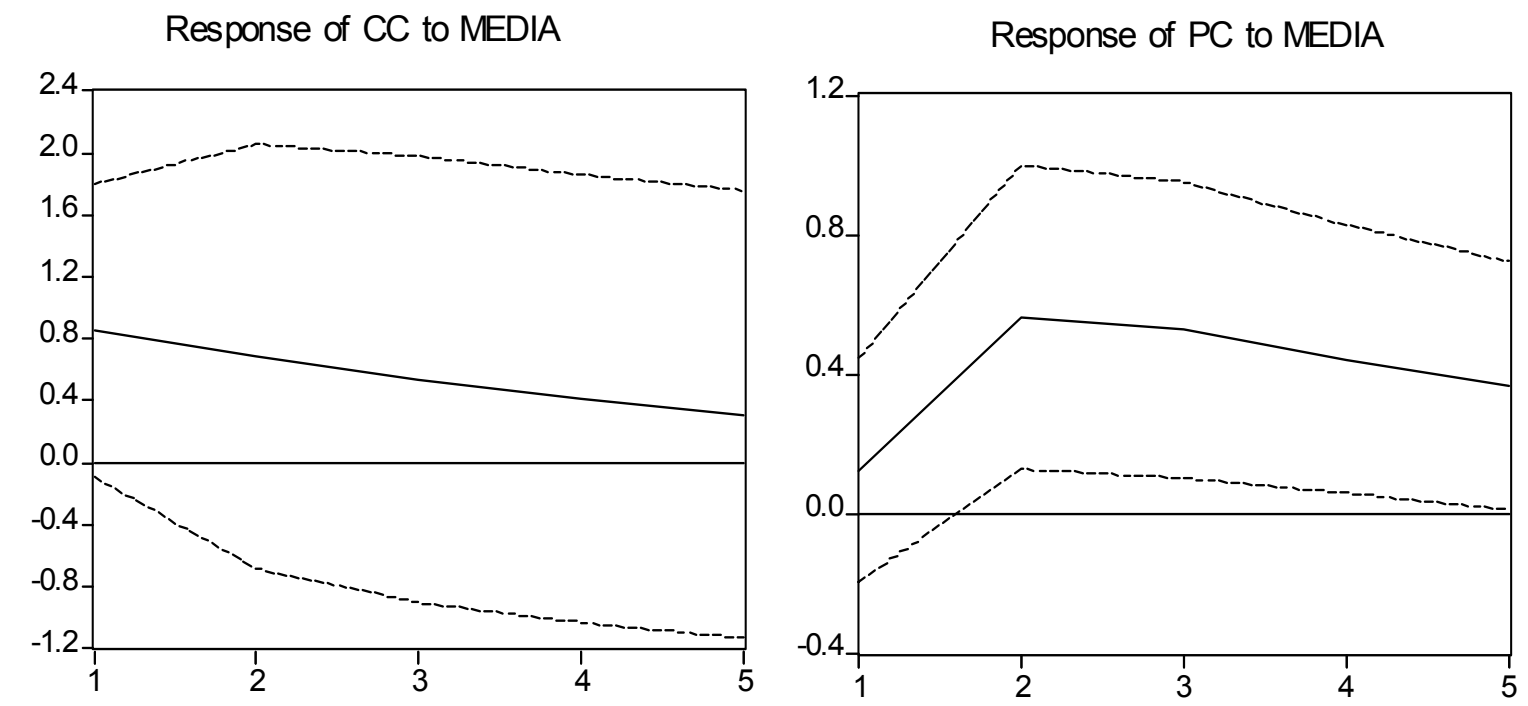

Figure 2 - Response of consumer confidence $(C C)$ and producer confidence $(P C)$ of a one standard deviation shock to $M E D I A$ (dotted lines are two standard response deviations which serve as confidence intervals).

Figure 2 shows that MEDIA has a significant short-run effect on consumer confidence, but not on producer confidence. In the longer run the media impact on consumer confidence disappears. This is not surprising, since nothing is as old as yesterday's newspaper. In the longer run actual movements in the economy, as mainly reflected in producer confidence, affect each other. This can be understood because the media follow long-run movements in the economy and as such are closely related to producer confidence.

Other variables might, of course also, affect CC or PC. Jansen and Nahuis (2003) have found a strong effect of stock market indices on CC. We now also introduce a stock market index (AEX) to the VAR and again perform impulse-response analyses. ${ }^{8}$

\footnotetext{
${ }^{8}$ In this VAR the Cholesky ordering in the impulse-response analysis is AEX, MEDIA, CC and PC. The optimal number of lags remains one. We also experimented with unemployment as an additional variable. In a qualitative sense this gives similar results compared to those with respect to the AEX.
} 
Table 4 - Unrestricted VAR(1) estimates for the period February1998 until December 2002, $t$-values between brackets

\begin{tabular}{|c|c|c|c|c|}
\hline \multicolumn{5}{|c|}{$\begin{array}{l}\text { Model: } \mathbf{y}_{t}=\mathbf{A}_{\mathbf{0}}+\mathbf{A}_{\mathbf{1}} \mathbf{y}_{t-1}+\boldsymbol{\varepsilon}_{t} \\
\text { where } \mathbf{y}_{t}=(C C, P C, M E D I A, A E X)^{\prime}\end{array}$} \\
\hline & $A E X$ & MEDIA & $C C$ & $P C$ \\
\hline \multirow[t]{2}{*}{$A E X(-1)$} & 0.638 & -0.003 & -0.008 & -0.003 \\
\hline & $(8.921)$ & $(-2.435)$ & $(-0.886)$ & $(-0.870)$ \\
\hline \multirow[t]{2}{*}{$M E D I A(-1)$} & -15.068 & 0.055 & -0.471 & 0.909 \\
\hline & $(-1.680)$ & $(0.407)$ & $(-0.404)$ & (2.334) \\
\hline \multirow[t]{2}{*}{$C C(-1)$} & 3.191 & 0.027 & 1.047 & 0.057 \\
\hline & $(5.033)$ & $(2.778)$ & (12.694) & $(2.070)$ \\
\hline \multirow[t]{2}{*}{$P C(-1)$} & -1.038 & -0.005 & -0.203 & 0.800 \\
\hline & $(-0.660)$ & $(-0.203)$ & $(-0.992)$ & $(11.721)$ \\
\hline \multirow[t]{2}{*}{ Constant } & 183.827 & 3.883 & 6.030 & -2.048 \\
\hline & $(4.294)$ & $(6.023)$ & (1.083) & $(-1.102)$ \\
\hline \multirow[t]{2}{*}{ Trend } & 1.172 & 0.001 & -0.031 & 0.031 \\
\hline & $(2.674)$ & $(0.076)$ & $(-0.545)$ & $(1.621)$ \\
\hline Observations & 59 & 59 & 59 & 59 \\
\hline Adj. R-squared & 0.904 & 0.377 & 0.956 & 0.897 \\
\hline S.E. equation & 28.358 & 0.427 & 3.688 & 1.231 \\
\hline F-statistic & 110.636 & 8.028 & 250.565 & 101.494 \\
\hline Akaike AIC & 9.624 & 1.233 & 5.544 & 3.350 \\
\hline
\end{tabular}


Response to Cholesky One S.D. Innovations \pm 2 S.E.

Response of CC to AEX

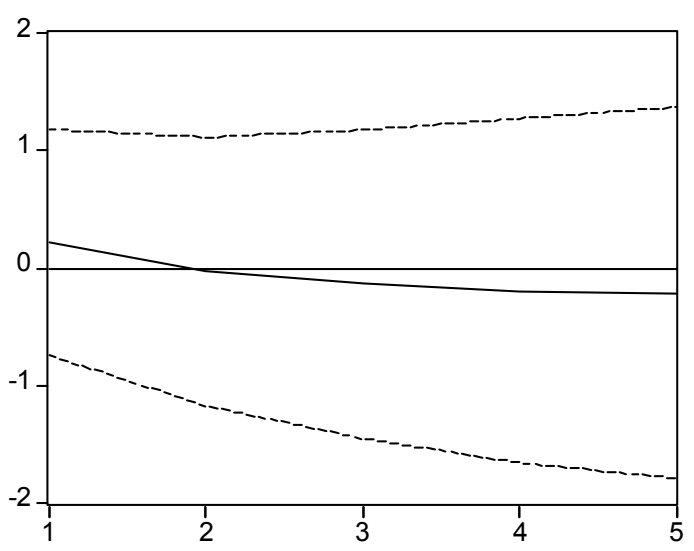

Response of PC to AEX

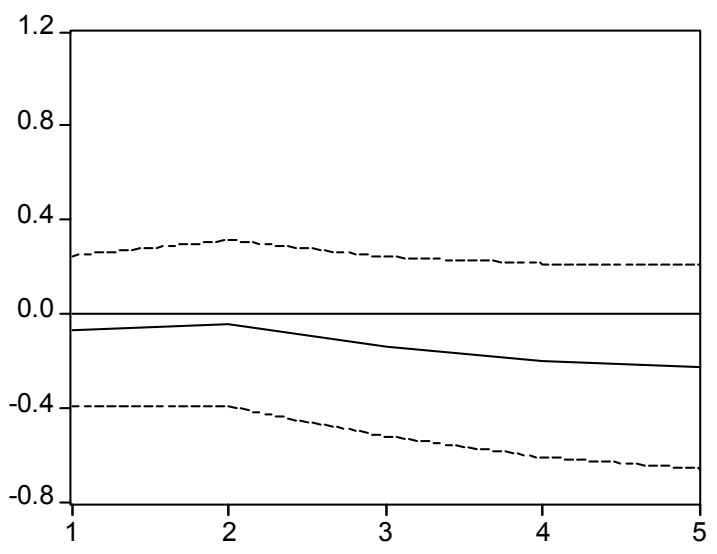

Response of CC to MEDIA

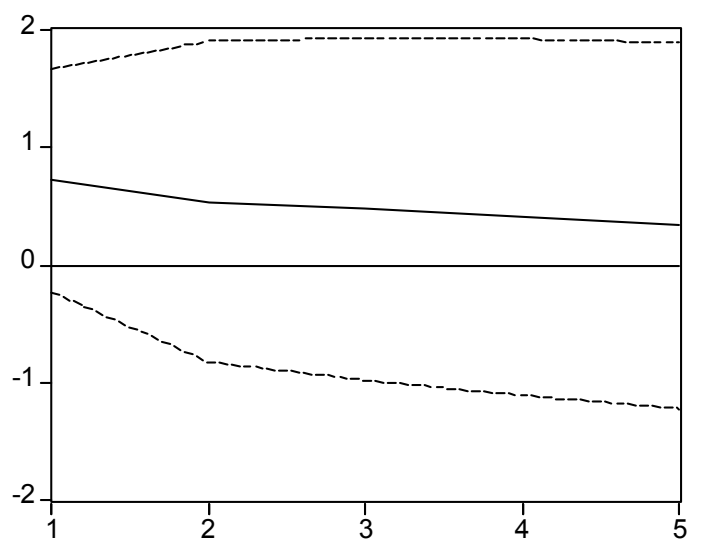

Response of PC to MEDIA

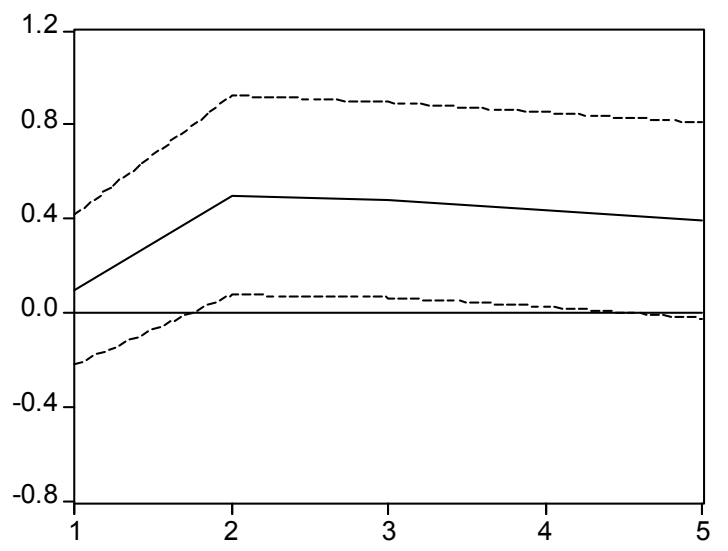

Figure 3 -Response of consumer confidence $(C C)$ and producer confidence $(P C)$ of a one standard deviation shock of stock market index (AEX) and MEDIA

As is clear from figure 3, including the AEX makes no noticeable difference in terms of impulse-response analyses. $M E D I A$ continues to have a short-run significant impact on consumer confidence, but does not influence producer confidence in the short run. In the long run, however, MEDIA is only related to producer confidence and not to consumer confidence. The stock market index, AEX, does not have a significant impact on both consumer- and producer confidence. The short-term effect of Media confirms our hypothesis with respect to the magnifying effect of Media. The long-term effect seems inconsistent with the hypothesis. However, it can be expected that in the longer run MEDIA affects consumer spending and thus also PP. 


\section{CONCLUSION AND EVALUATION}

Competition forces newspapers to write memorable stories. One way of writing memorable stories is to spin the facts. Once such spinned stories get stuck in the minds of readers, it might be expected that the opinion of readers on the state of the economy is affected by such stories: sentiments about actual changes in the economy are magnified by newspaper reports. Our hypothesis is as follows: consumer confidence is not only affected by the actual state of the economy, but also by spin. By using a VAR-model we are able to separate these effects from each other.

We have found some evidence for spin bias in Dutch newspapers' articles on the state of the economy in the period 1998 until 2003. In line with this hypothesis consumer confidence is more volatile than producer confidence. This is, however, a rather weak test. The higher volatility of consumer confidence may be caused by other factors than the existence of spin bias.

Subsequently, we estimated a VAR system with producer confidence, consumer confidence and media as variables. On the basis of this system we conducted impulse-response analyses with changes in MEDIA being the impulse. Changes in MEDIA have a significant, but shortlived effect on consumer confidence and no immediate effect on producer confidence. This is consistent with our hypothesis of spin bias, since such bias is not expected to have an impact on producer confidence, because the latter is only composed of objective variables. Finally, adding a stock market index to our VAR does not change the conclusions about the impact of MEDIA on producer and produces confidence.

As always there is room for further research. We found evidence for a magnifying effect of MEDIA on consumer confidence. Consistent with our hypothesis, we take this as evidence for the existence of spin. However, this does not rule out other possible explanations of this effect. For example, the mere fact that a story is written down in a newspaper might have an effect in the minds of readers, compared to stories that are, for example, orally distributed (although the selection of stories can in itself be an element of spin). Furthermore, whether or not stories contain spin could be analysed in a different manner. For example, a text analysis of a specific newspaper story compared to actual facts of that story could reveal exaggeration of the facts. The disadvantage of such a method is that it is a story-by-story approach that 
cannot easily be generalized. Finally, we only examined newspapers. Is the effect we find special for newspapers only, or does it also hold for other media, like radio or TV reporting? These qualifications are all very much topics for future research. 


\section{APPENDIX}

MEDIA - Monthly data for the period 1998-2002.

\begin{tabular}{llrl}
\hline PERIOD & MEDIA & PERIOD & MEDIA \\
\hline 1998:01 & 3.300000 & $2000: 07$ & 3.100000 \\
$1998: 02$ & 3.450000 & $2000: 08$ & 2.550000 \\
1998:03 & 3.650000 & $2000: 09$ & 2.800000 \\
$1998: 04$ & 3.000000 & $2000: 10$ & 3.000000 \\
$1998: 05$ & 3.650000 & $2000: 11$ & 2.500000 \\
$1998: 06$ & 3.350000 & $2000: 12$ & 2.450000 \\
$1998: 07$ & 3.200000 & $2001: 01$ & 2.350000 \\
$1998: 08$ & 2.700000 & $2001: 02$ & 2.600000 \\
$1998: 09$ & 2.500000 & $2001: 03$ & 2.950000 \\
$1998: 10$ & 1.550000 & $2001: 04$ & 2.150000 \\
$1998: 11$ & 3.100000 & $2001: 05$ & 2.500000 \\
$1998: 12$ & 2.950000 & $2001: 06$ & 2.000000 \\
$1999: 01$ & 3.650000 & $2001: 07$ & 2.400000 \\
$1999: 02$ & 2.800000 & $2001: 08$ & 2.650000 \\
$1999: 03$ & 3.550000 & $2001: 09$ & 2.200000 \\
$1999: 04$ & 3.000000 & $2001: 10$ & 2.400000 \\
$1999: 05$ & 3.750000 & $2001: 11$ & 2.050000 \\
$1999: 06$ & 2.700000 & $2001: 12$ & 1.850000 \\
$1999: 07$ & 3.250000 & $2002: 01$ & 2.950000 \\
$1999: 08$ & 3.150000 & $2002: 02$ & 3.100000 \\
$1999: 09$ & 3.400000 & $2002: 03$ & 2.350000 \\
$1999: 10$ & 2.650000 & $2002: 04$ & 2.450000 \\
$1999: 11$ & 2.900000 & $2002: 05$ & 2.000000 \\
$1999: 12$ & 3.200000 & $2002: 06$ & 1.550000 \\
$2000: 01$ & 4.050000 & $2002: 07$ & 2.850000 \\
$2000: 02$ & 3.400000 & $2002: 08$ & 2.100000 \\
$2000: 03$ & 2.950000 & $2002: 09$ & 2.850000 \\
$2000: 04$ & 2.900000 & $2002: 10$ & 2.650000 \\
$2000: 05$ & 2.900000 & $2002: 11$ & 2.200000 \\
$2000: 06$ & 3.300000 & $2002: 12$ & 2.700000 \\
\hline & & &
\end{tabular}




\section{REFERENCES}

Jansen, M. (2003), Consumentenvertrouwen als indicatie voor de toekomstige particuliere consumptie (Consumer Confidence as an Indicator of Future Private Consumption), CBS (Statistics Netherlands), Divisie Macro-Economische Statistieken en Publicaties, Voorburg.

Jansen, W.J., and N.J. Nahuis (2003), The Stock Market and Consumer confidence: European Evidence, Economic Letters, Vol.79, pp. 89-98.

Mullainathan, S. and A. Shleifer (2002), Media Bias, NBER Working Paper, Nr. 9295 , Cambridge, Mass.

Woltman Elpers, J.L.C.M., M. Wedel and F.G.M. Pieters (2003), "Why do Consumers stop watching TV Commercials? Two Experiments on the Influence of Moment-toMoment Entertainment and Information Value", Journal of Marketing Research, November 2003, pp. pp. 437-453.

NR feitenboekje (2003) ('Book with NR facts'), Carat Nederland, Amsterdam.

Ludvigson, S.C. (2004), Consumer Confidence and Consumer Spending, Journal of Economic Perspectives, Vol. 18, pp. 29-50.

Malhotra, N.K. (2003), Marketing Research, an applied orientation, 4th ed, Pearson Education, Upper Saddle River, New Jersey. 


\title{
CESifo Working Paper Series
}

\author{
(for full list see www.cesifo.de)
}

1265 Hans-Werner Sinn, Migration, Social Standards and Replacement Incomes. How to Protect Low-income Workers in the Industrialized Countries against the Forces of Globalization and Market Integration, August 2004

1266 Wolfgang Leininger, Fending off one Means Fending off all: Evolutionary Stability in Submodular Games, August 2004

1267 Antoine Bommier and Bertrand Villeneuve, Risk Aversion and the Value of Risk to Life, September 2004

1268 Harrie A. A. Verbon and Lex Meijdam, Too Many Migrants, Too Few Services: A Model of Decision-making on Immigration and Integration with Cultural Distance, September 2004

1269 Thomas Eichner and Rüdiger Pethig, Economic Land Use, Ecosystem Services and Microfounded Species Dynamics, September 2004

1270 Federico Revelli, Performance Rating and Yardstick Competition in Social Service Provision, September 2004

1271 Gerhard O. Orosel and Klaus G. Zauner, Vertical Product Differentiation When Quality is Unobservable to Buyers, September 2004

1272 Christoph Böhringer, Stefan Boeters, and Michael Feil, Taxation and Unemployment: An Applied General Equilibrium Approach, September 2004

1273 Assaf Razin and Efraim Sadka, Welfare Migration: Is the Net Fiscal Burden a Good Measure of its Economics Impact on the Welfare of the Native-Born Population?, September 2004

1274 Tomer Blumkin and Volker Grossmann, Ideological Polarization, Sticky Information, and Policy Reforms, September 2004

1275 Katherine Baicker and Nora Gordon, The Effect of Mandated State Education Spending on Total Local Resources, September 2004

1276 Gabriel J. Felbermayr and Wilhelm Kohler, Exploring the Intensive and Extensive Margins of World Trade, September 2004

1277 John Burbidge, Katherine Cuff and John Leach, Capital Tax Competition with Heterogeneous Firms and Agglomeration Effects, September 2004

1278 Joern-Steffen Pischke, Labor Market Institutions, Wages and Investment, September 2004 
1279 Josef Falkinger and Volker Grossmann, Institutions and Development: The Interaction between Trade Regime and Political System, September 2004

1280 Paolo Surico, Inflation Targeting and Nonlinear Policy Rules: The Case of Asymmetric Preferences, September 2004

1281 Ayal Kimhi, Growth, Inequality and Labor Markets in LDCs: A Survey, September 2004

1282 Robert Dur and Amihai Glazer, Optimal Incentive Contracts for a Worker who Envies his Boss, September 2004

1283 Klaus Abberger, Nonparametric Regression and the Detection of Turning Points in the Ifo Business Climate, September 2004

1284 Werner Güth and Rupert Sausgruber, Tax Morale and Optimal Taxation, September 2004

1285 Luis H. R. Alvarez and Erkki Koskela, Does Risk Aversion Accelerate Optimal Forest Rotation under Uncertainty?, September 2004

1286 Giorgio Brunello and Maria De Paola, Market Failures and the Under-Provision of Training, September 2004

1287 Sanjeev Goyal, Marco van der Leij and José Luis Moraga-González, Economics: An Emerging Small World?, September 2004

1288 Sandro Maffei, Nikolai Raabe and Heinrich W. Ursprung, Political Repression and Child Labor: Theory and Empirical Evidence, September 2004

1289 Georg Götz and Klaus Gugler, Market Concentration and Product Variety under Spatial Competition: Evidence from Retail Gasoline, September 2004

1290 Jonathan Temple and Ludger Wößmann, Dualism and Cross-Country Growth Regressions, September 2004

1291 Ravi Kanbur, Jukka Pirttilä and Matti Tuomala, Non-Welfarist Optimal Taxation and Behavioral Public Economics, October 2004

1292 Maarten C. W. Janssen, José Luis Moraga-González and Matthijs R. Wildenbeest, Consumer Search and Oligopolistic Pricing: An Empirical Investigation, October 2004

1293 Kira Börner and Christa Hainz, The Political Economy of Corruption and the Role of Financial Institutions, October 2004

1294 Christoph A. Schaltegger and Lars P. Feld, Do Large Cabinets Favor Large Governments? Evidence from Swiss Sub-Federal Jurisdictions, October 2004

1295 Marc-Andreas Mündler, The Existence of Informationally Efficient Markets When Individuals Are Rational, October 2004 
1296 Hendrik Jürges, Wolfram F. Richter and Kerstin Schneider, Teacher Quality and Incentives: Theoretical and Empirical Effects of Standards on Teacher Quality, October 2004

1297 David S. Evans and Michael Salinger, An Empirical Analysis of Bundling and Tying: Over-the-Counter Pain Relief and Cold Medicines, October 2004

1298 Gershon Ben-Shakhar, Gary Bornstein, Astrid Hopfensitz and Frans van Winden, Reciprocity and Emotions: Arousal, Self-Reports, and Expectations, October 2004

1299 B. Zorina Khan and Kenneth L. Sokoloff, Institutions and Technological Innovation During Early Economic Growth: Evidence from the Great Inventors of the United States, 1790 - 1930, October 2004

1300 Piero Gottardi and Roberto Serrano, Market Power and Information Revelation in Dynamic Trading, October 2004

1301 Alan V. Deardorff, Who Makes the Rules of Globalization?, October 2004

1302 Sheilagh Ogilvie, The Use and Abuse of Trust: Social Capital and its Deployment by Early Modern Guilds, October 2004

1303 Mario Jametti and Thomas von Ungern-Sternberg, Disaster Insurance or a Disastrous Insurance - Natural Disaster Insurance in France, October 2004

1304 Pieter A. Gautier and José Luis Moraga-González, Strategic Wage Setting and Coordination Frictions with Multiple Applications, October 2004

1305 Julia Darby, Anton Muscatelli and Graeme Roy, Fiscal Federalism, Fiscal Consolidations and Cuts in Central Government Grants: Evidence from an Event Study, October 2004

1306 Michael Waldman, Antitrust Perspectives for Durable-Goods Markets, October 2004

1307 Josef Honerkamp, Stefan Moog and Bernd Raffelhüschen, Earlier or Later: A General Equilibrium Analysis of Bringing Forward an Already Announced Tax Reform, October 2004

1308 M. Hashem Pesaran, A Pair-Wise Approach to Testing for Output and Growth Convergence, October 2004

1309 John Bishop and Ferran Mane, Educational Reform and Disadvantaged Students: Are They Better Off or Worse Off?, October 2004

1310 Alfredo Schclarek, Consumption and Keynesian Fiscal Policy, October 2004

1311 Wolfram F. Richter, Efficiency Effects of Tax Deductions for Work-Related Expenses, October 2004 
1312 Franco Mariuzzo, Patrick Paul Walsh and Ciara Whelan, EU Merger Control in Differentiated Product Industries, October 2004

1313 Kurt Schmidheiny, Income Segregation and Local Progressive Taxation: Empirical Evidence from Switzerland, October 2004

1314 David S. Evans, Andrei Hagiu and Richard Schmalensee, A Survey of the Economic Role of Software Platforms in Computer-Based Industries, October 2004

1315 Frank Riedel and Elmar Wolfstetter, Immediate Demand Reduction in Simultaneous Ascending Bid Auctions, October 2004

1316 Patricia Crifo and Jean-Louis Rullière, Incentives and Anonymity Principle: Crowding Out Toward Users, October 2004

1317 Attila Ambrus and Rossella Argenziano, Network Markets and Consumers Coordination, October 2004

1318 Margarita Katsimi and Thomas Moutos, Monopoly, Inequality and Redistribution Via the Public Provision of Private Goods, October 2004

1319 Jens Josephson and Karl Wärneryd, Long-Run Selection and the Work Ethic, October 2004

1320 Jan K. Brueckner and Oleg Smirnov, Workings of the Melting Pot: Social Networks and the Evolution of Population Attributes, October 2004

1321 Thomas Fuchs and Ludger Wößmann, Computers and Student Learning: Bivariate and Multivariate Evidence on the Availability and Use of Computers at Home and at School, November 2004

1322 Alberto Bisin, Piero Gottardi and Adriano A. Rampini, Managerial Hedging and Portfolio Monitoring, November 2004

1323 Cecilia García-Peñalosa and Jean-François Wen, Redistribution and Occupational Choice in a Schumpeterian Growth Model, November 2004

1324 William Martin and Robert Rowthorn, Will Stability Last?, November 2004

1325 Jianpei Li and Elmar Wolfstetter, Partnership Dissolution, Complementarity, and Investment Incentives, November 2004

1326 Hans Fehr, Sabine Jokisch and Laurence J. Kotlikoff, Fertility, Mortality, and the Developed World's Demographic Transition, November 2004

1327 Adam Elbourne and Jakob de Haan, Asymmetric Monetary Transmission in EMU: The Robustness of VAR Conclusions and Cecchetti's Legal Family Theory, November 2004

1328 Karel-Jan Alsem, Steven Brakman, Lex Hoogduin and Gerard Kuper, The Impact of Newspapers on Consumer Confidence: Does Spin Bias Exist?, November 2004 